\title{
Protective effects of whey protein mixed with Garcinia kola and olive leaves extract against alloxan-induced oxidative stress and diabetes in rats
}

\author{
A M Abdel-Salam ${ }^{1 *}$, M S Ismail ${ }^{2}$, M M Farahna $^{3}$ and $\mathrm{H} \mathrm{M} \mathrm{Mousa}^{4}$
}

\begin{abstract}
Background: Manipulation of functional dairy products and natural phytochemicals may be a good source of micronutrients for traditional therapies and improve the hypoglycemia. The objective of this study to find out the protective effects of whey protein (WP) mixed with Garcinia kola seeds (GK) and extract of olive leaves (OL) against alloxan-induced oxidative stress and diabetes in rats.

Methods: The 42 male Sprague-Dawley rats (120-150 g) were housed individually and randomly allocated to two main groups; normal group $(n=6)$ and six equal alloxan-induced diabetic groups $(n=36)$. Normal (first) and diabetic control (second) groups received basal diet only during the experiment, while groups (third, fourth, fifth, sixth, and seventh) received basal diet and an oral extract from WB (300 mg/day); OL (200 mg/day); WP and OL mixture $(300+200 \mathrm{mg} /$ day); GK (15 mg/day); and WP and GK mixture (300 + 15 mg/day) respectively. Biochemical markers including hematological parameters, glucose, BUN, creatinine, albumin, total protein, and liver enzymes were determined. Brain sample were taken for histopathological examination.

Results: In comparison with second group, the administration of WP, GK, OL, WP and GK mixture, and WP and OL extracts respectively resulted in significant decrease in blood glucose $(61.0 \pm 10.8,68.5 \pm 6.6,64.8 \pm 14.6,82.2 \pm 8.4$, and $91.7 \pm 20$ vs. $135.6 \mathrm{mg} / \mathrm{dl} \pm 12.3$ respectively). Liver enzymes were improved with administration of WP, GK, and OL extracts compared with positive control. Brain histopathological investigation showed reduction in tissue changes among rats received the suggested interventions.

Conclusions: The obtained data can be concluded that administration of WP, GK, and OL extracts had evident favorable effects on blood glucose, major hematological, and biochemical parameters as well as the histological picture of brain.
\end{abstract}

Keywords: Whey protein, Garcinia kola, Olive leaves extract, Diabetes, Rat

\section{Background}

Cardiovascular disease is increased worldwide rapidly and is estimated to be the leading cause of death in developing countries. Cardiovascular complications are observed in both type 1 and type 2 diabetic patients, and it is responsible for the increasing risk of vascular diseases (WHO, 2009, Bloomgarden 2002).

\footnotetext{
* Correspondence: amsalam68@hotmail.com

${ }^{1}$ Dairy Science Department, National Research Centre, Dokki, Cairo, Egypt Full list of author information is available at the end of the article
}

Whey protein is a high quality, complete protein, and containing all essential amino acids required by the human body. Whey protein is naturally bioactive which basically contains high concentrations of cysteine and consequently glutathione-an antioxidant that is essential for improving human health. Whey protein concentrate increased the preventive factors and reduce the oxidative stress factors and rise the resistance factors in human cells (Konok et al. 1995; Baruchel and Viaux 1996).

Garcinia kola (family-Guttifera) also known as bitter kola, false kola, and male kola, and it is an evergreen, 
dicotyledonous plant found in moist forest, riverine, and swampy areas. It occurs naturally in Sierra Leone, Nigeria, and Angola. The seeds have a bitter taste and have been consumed as an intoxicating against liver disorders, diarrhea, diabetes, bronchitis, and throat infections. Garcinia kola has also been reported to possess some hepatoprotective and aphrodisiac properties (Atawodi et al. 1995; Tita et al. 2001).

Olive leaves derived from olive tree (Olea europaea) are obtained as by-product during oil extraction. The olive leaves were first used medicinally in Ancient Egypt, and it was a symbol of heavenly power. The extracts of olive leaves have been used medicinally in the human diet and used as an herbal tea. Olive leaves contain many of bioactive compounds that have more benefits as antioxidant, antihypertensive, antiatherogenic, anti-inflammatory, hypocholesterolemic, and hypoglycemic properties (Mousa et al. 2014). It is traditionally used in developing countries as an alternative source of nutrients for animals during feed scarcity (García et al. 2003). Leaves have been widely used in traditional remedies in European and Mediterranean countries. Interest in the olive leave beneficial effects has recently being increasing. It was reported that Ancient Egyptians used olive leaf for mummification and as a remedy against various diseases. Many studies used them to treat Malaria and leukemia (Markin et al. 2003, Abaza et al. 2007). They have been used in the human diet as an extract, herbal tea, and a powder, and they contain many potentially bioactive compounds that may have anti-inflammatory properties (Tuck and Ilayball 2002; Bitler et al. 2005), anti-thrombic actions (Carluccio et al. 2003), prevention against LDL oxidation (Bagheri and Ahmadvand 2011), hypoglycemic effects (Wainstein et al. 2012; Sato et al. 2007), anti-ischemic and hypolipidemic effects, antioxidant, and antihypertensive agent (Andreadou et al. 2006).

The aim of the present study was to investigate the hypoglycemic and protective characteristics of whey protein either alone or mixed with Garcinia kola seeds and olive leaves extract against alloxan-induced oxidative stress and diabetes in rats.

\section{Methods}

\section{Garcinia kola, olive leaves, and whey proteins}

Garcinia kola seeds presumably from Nigeria were purchased from Nigerians market, Makkah, Saudi Arabia. Green olive leaves, which were used in this experiment, were grown in Al-Qassim region, Saudi Arabia. G. kola seeds and green olive leaves were collected, dried, grinded, and stored until use. Powdered whey proteins were purchased from GNC, USA. The composition and nutritional values of whey proteins concentrate used in this study per $100 \mathrm{~g}$ are as follows: calories (392.68), total fat $(7.14 \%)$, total carbohydrates $(7.14 \%)$, and protein
(75.0\%). The experiments were carried out between the time period of March and April 2014 in the animal Lab at Faculty of Agriculture and Veterinary Medicine, Qassim University, Saudi Arabia.

\section{Animals and experimental design Animals}

Forty-two male Sprague-Dawley rats $(n=42)$ weighing 120-150 g were purchased from Animal Unit, Faculty of Pharmacy, King Saud University, Saudi Arabia. The rats were kept in a positive/negative control housing unit, having ventilated caging system, obtained from Allentown, Pennsylvania, USA. Rats were housed at $22{ }^{\circ} \mathrm{C}$, $56 \%$ humidity (40 to $70 \%$ ) in Allentown cages, and in a 12-h light/12-h dark cycle. Rats were provided with free access to tap water and food. The experimental animals were treated in conformity according the European Union Directive for animal use in scientific research (European Directive 2010). Animal procedures were performed in accordance with the approved procedures by Institutional Ethical Committee.

\section{Diet and aqueous extracts}

The basal diet used was bought from the Animal Unit of Faculty of Pharmacy in King Saud University, Saudi Arabia. The diet possessed energy of $2850.0 \mathrm{kcal} / \mathrm{kg}$; $64.0 \%$ carbs; $4.0 \%$ crude fat; $20.0 \%$ crude protein; $3.5 \%$ crude fiber; $0.50 \%$ salt; $6.0 \%$ ash; vitamin A $20.0 \mathrm{IU} / \mathrm{g}$; and trace elements, including Cobalt, Copper, Iodine, Iron, Manganese, Selenium, and Zinc. The experimental animals were treated in conformity according the European Union Directive for animal use in scientific research (European Directive 2010). Animal procedures were performed in accordance with the approved procedures by Institutional Ethical Committee. The hot-water extraction of olive leaves was prepared according the methods described by Abdel-Salam et al. (2009). The final extraction of olive leaves was at $60 \mathrm{~g} / \mathrm{L}(6 \%)$ as total dry leaves. However, the final concentrations of the prepared whey proteins concentrate solution were $3 \%$ as total solids in distilled water. To ensure the delivery of suggested amounts from all supplements suggested here, all of these supplements were first prepared as aqueous solution and secondly given orally to each rat of intervention groups.

\section{Experimental design}

For induction of diabetes, 36 rats were intraperitoneally (IP) injected with alloxan at a dose of $150 \mathrm{mg} / \mathrm{kg}$ body weight. After, $72 \mathrm{~h}$ fasting blood samples were collected from the retro-orbital veins for determination of glucose. Rats, who have blood glucose level $>250 \mathrm{mg} / \mathrm{dl}$ were taken as diabetic rats and recruited in the experiment. Simultaneously, blood glucose for the normal control group was determined at the beginning of the experiment. 
After $72 \mathrm{~h}$ of alloxan injection, blood glucose was determined for all normal (6 rats) and diabetic rats (36 rats), and rats were weighed and distributed in the experimental groups. The 42 rats in this study were sub-grouped equally (6 rats for each group) as follows:

First group (NC) is negative control group and fed basal diet only.

Second group (DC) is the diabetic control group and fed basal diet only as well.

Third group (WP) composed of 6 diabetic rats and fed basal diet plus $300 \mathrm{mg} /$ day whey protein.

Fourth group (OL) composed of 6 diabetic rats and fed basal diet plus olive leaves extracts $(200 \mathrm{mg} /$ day).

Fifth group (WPOL) composed of 6 diabetic rats and fed on basal diet plus mixture of whey protein and olive leaves extract (300 $\mathrm{mg}$ and $200 \mathrm{mg}$ /day respectively).

Sixth group (GK) composed of 6 diabetic rats and fed on basal diet plus G. kola seeds (15 mg/day).

Seventh group (WPGK) composed of 6 diabetic rats and fed on basal diet plus mixture of whey protein and G. kola (300 $\mathrm{mg}$ and $15 \mathrm{mg} /$ day respectively).

\section{Blood sampling, laboratory analysis, and histopathology}

At the completion of experiment (28 days), blood samples were collected from control and diabetic groups after $8 \mathrm{~h}$ fasting. The experiment comprised of the rats that were given ether anesthetized, when scarified. Blood samples were taken from hepatic portal vein in two tubes; the blood in the first tube was used directly for determination of hematological parameters, and the second tube were centrifuged directly for the duration of $10 \mathrm{~min}$ at $3000 \mathrm{rpm}$ in order to separate the serum. Later, the serum was carefully transferred after aspiration into clean tubes and stored at $-20{ }^{\circ} \mathrm{C}$ frozen for analysis.

Hematological parameters included white blood cell count (WBC), hemoglobin (Hgb), hematocrit (Hct), mean corpuscular volume (MCV), mean corpuscular hemoglobin $(\mathrm{MCH})$, mean corpuscular hemoglobin concentration (MCHC), red cell distribution width (RDW), platelet count (PLT), and mean platelet volume (MPV) were determined by automated hematology analyzer using Beckman Coulter system with the manual methods (Beckman Coulter, Inc.). Using the standard and official methods, the separated serum was used for determination of activities of liver enzymes (i.e., alanine transferase (ALT) aspartate transaminase (AST) according to the method of Reitman and Frankel (1957), and alkaline phosphatase according to the method of Kind and King (1954). Serum total protein was determined according to the method described by King and Woolton (1956). Serum albumin was estimated according to the method described by Drupt (1974). Serum triglycerides were determined according to Fossati and Prencipe
(1982), blood glucose values according to the method of Brodrick et al. (1987), triglycerides according to the method of Fossati and Prencipe (1982), creatinine according to the method of Bonnes and Taussky (1945), and Urea was determined in serum according to the method of Tietz (1970).

Brain samples were taken and quickly fixed in $10 \%$ formalin for $24 \mathrm{~h}$. Paraffin sections, $6 \mu \mathrm{m}$ thick, were prepared and stained with hematoxylin and eosin (H\&E) for the histopathological examination (Humason 1979).

\section{Statistical analyses}

All obtained data was statistically analyzed and presented as mean $\pm \mathrm{SD}$, also the significant differences between different groups were calculated by ANOVA followed by Duncan's multiple range test with $P \leq 0.05$ being considered statistically significant (Steel et al. (1997)). Statistical analysis was conducted with SAS program (SAS 1996).

\section{Results}

Tables 1 and 2 showed the effect of the administration of whey protein, olive leaves extract, and G. kola on hematological parameters. As shown, no clear or significant differences had been observed between different groups in relation to hematological parameters. Although there were no significant differences, but results of Tables 1 and 2 showed that the mean values of white blood cells were high in positive control and diabetic group fed on $G$. kola (GK) compared with normal group. Meanwhile, the values of white blood cells were decreased with administration of whey protein mixed with G. kola (WPGK).

Tables 3 and 4 showed the effect of whey protein, G. kola, and olive leaves extract on biochemical markers in diabetic rats. As shown in Tables 3 and 4, in comparison with diabetic control group, the blood glucose levels were significantly lower in WP, OL, and GK groups $(61.0 \pm 10.8$, $64.8 \pm 14.6$ and $68.5 \pm 6.6$ vs. $135.6 \pm 12.3 \mathrm{mg} / \mathrm{dl}$ respectively). In parallel, the mean values of blood glucose among WP, GK and WP, OL groups were $82.2 \pm 8.4$ and $91.7 \pm$ $20.0 \mathrm{mg} / \mathrm{dl}$ respectively which were significantly $(P<0.05)$ lower than values of DC group $(135.6 \pm 12.3 \mathrm{mg} / \mathrm{dl})$.

Regarding total proteins and total albumin, the data showed a slight variations and differences between the treated groups and positive control group. As shown in Tables 3 and 4, there was a significant decrease in the activities of AST and ALT in diabetic rats that received both of WPGK and WPOL compared with the positive control. When compared with other groups, the olive leaves extract caused the highest reduction in the activities of ALP enzyme. In contrary, whey protein caused the highest increase in the activities of ALP enzyme. The mean values of urea in diabetic rats fed WP, OL, and WPOL were the highest values when compared with other groups. Also, the mean values of creatinine in diabetic rats fed on of OL and WPOL were the highest values. 
Table 1 Mean \pm SD of hematological parameters of diabetic rats fed on whey protein, olive leaves extracts and their mixture

\begin{tabular}{|c|c|c|c|c|c|c|c|}
\hline & \multirow{2}{*}{$\begin{array}{l}\mathrm{NC}(n=6) \\
\text { Mean } \pm S D\end{array}$} & \multirow{2}{*}{$\begin{array}{l}\text { DC }(n=6) \\
\text { Mean } \pm S D\end{array}$} & \multirow{2}{*}{$\begin{array}{l}\text { WP }(n=6) \\
\text { Mean } \pm \text { SD }\end{array}$} & \multirow{2}{*}{$\begin{array}{l}\mathrm{OL}(n=6) \\
\text { Mean } \pm \text { SD }\end{array}$} & \multirow{2}{*}{$\begin{array}{l}\text { WPOL }(n=6) \\
\text { Mean } \pm \text { SD }\end{array}$} & \multicolumn{2}{|l|}{ ANOVA } \\
\hline & & & & & & $F$ value & Sig. \\
\hline$\overline{W B C}\left(10^{3} \mu \mathrm{l}\right)$ & $10.8 \pm 1.2$ & $18.4 \pm 5.3$ & $13.1 \pm 3.2$ & $14.6 \pm 3.9$ & $14.6 \pm 3.5$ & 2.7 & 0.057 \\
\hline $\mathrm{RBC}\left(10^{6} \mu \mathrm{l}\right)$ & $8.0 \pm 0.5$ & $8.0 \pm 0.5$ & $7.5 \pm 0.6$ & $7.9 \pm 0.4$ & $8.1 \pm 0.5$ & 1.1 & 0.364 \\
\hline $\mathrm{Hgb}(\mathrm{g} / \mathrm{dl})$ & $15.1 \pm 1.1$ & $16.0 \pm 0.7$ & $15.1 \pm 1.1$ & $15.9 \pm 1.1$ & $15.9 \pm 0.7$ & 1.2 & 0.322 \\
\hline Hct (\%) & $44.3 \pm 3.8$ & $46.4 \pm 1.6$ & $44.1 \pm 2.7$ & $48.0 \pm 3.8$ & $48.0 \pm 1.9$ & 2.4 & 0.077 \\
\hline $\mathrm{MCV}(\mathrm{fl})$ & $55.5 \pm 2.1$ & $58.3 \pm 2.5$ & $58.8 \pm 0.8$ & $60.3 \pm 2.2$ & $59.7 \pm 2.1$ & 3.8 & $0.017^{*}$ \\
\hline $\mathrm{MCH}(\mathrm{pg})$ & $18.9 \pm 0.6$ & $20.1 \pm 1.0$ & $20.1 \pm 0.5$ & $20.0 \pm 0.5$ & $19.7 \pm 0.9$ & 2.0 & 0.126 \\
\hline $\mathrm{MCHC}(\mathrm{g} / \mathrm{dl})$ & $34.2 \pm 0.8$ & $34.5 \pm 0.6$ & $34.2 \pm 0.7$ & $33.2 \pm 0.7$ & $33.0 \pm 0.5$ & 6.2 & $0.002^{* *}$ \\
\hline RDW (\%) & $11.9 \pm 0.6$ & $12.1 \pm 0.9$ & $12.7 \pm 1.1$ & $12.9 \pm 0.6$ & $13.3 \pm 1.8$ & 1.4 & 0.280 \\
\hline $\mathrm{PLT}\left(10^{3} \mathrm{ml}\right)$ & $613.3 \pm 88.5$ & $794.7 \pm 83.6$ & $837.2 \pm 238.5$ & $882.7 \pm 104$ & $860.0 \pm 74.1$ & 3.1 & $0.037^{*}$ \\
\hline MPV (fL) & $5.7 \pm 0.4$ & $6.0 \pm 0.1$ & $5.4 \pm 0.2$ & $6.5 \pm 0.4$ & $6.6 \pm 0.6$ & 10.4 & $0.000^{* * *}$ \\
\hline
\end{tabular}

NC normal control; DC diabetic control; WP whey protein; $O L$ olive leaves; WPOL whey protein and olive leaves; $n$ number of rats, SD standard deviation, and ANOVA analysis of variance; WBC white blood cells; RBC red blood cells; Hgb hemoglobin; $H c t$ hematocrit; $M C V$ mean corpuscular volume; $M C H$ mean corpuscular hemoglobin; $M C H C$ mean corpuscular hemoglobin concentration, RDW red cell distribution width; PLT platelet count; MPV mean platelet volume

Values subscribed in the same row with different letters showed significant differences $(P<0.05)$ between these values as calculated by ANOVA and LSD

${ }^{*} P<0.05,{ }^{* *} P<0.01$ and ${ }^{* * *} P<0.001$

The histopathological examinations of the brain were presented in Table 5, and it revealed a cellular and tissue changes in the positive control, including generalized and localized edema in the white matter of cerebrum and cerebellum, neuronal necrosis, and axonal demyelination. Administration of whey protein, G. kola, and olive leaves extract in diabetic rats improved the histological picture.

\section{Discussion}

Dairy products are an important source of protein which may play a role in metabolic diseases and reduction of glycemia. Whey protein is seen as a more attractive protein, an important amino acid source, and it provides a source of bioactive peptides with a range of physiological functions. Studies showed that whey protein can be used as for a potential therapeutic agent in the treatment of type 2 diabetes and reduction of postprandial glycemia (Sharma et al. 2011; Nagpal et al. 2011; Gannon et al. 1988). In the present research, whey protein, G. kola, and olive leaves extract were investigated against changes in some blood markers, enzyme activities, and brain histology in alloxan-induced diabetes rats. Administration of whey protein, G. kola, and olive leaves extract reduced significantly the blood glucose levels when compared with positive control. The reduction of blood glucose level by whey protein, G. kola, and olive leaves extract can be investigated that whey protein, G. kola,

Table 2 Mean \pm SD of hematological parameters of diabetic rats fed on whey protein, G. kola, and their mixture

\begin{tabular}{|c|c|c|c|c|c|c|c|}
\hline & \multirow{2}{*}{$\begin{array}{l}\mathrm{NC}(n=6) \\
\text { Mean } \pm \mathrm{SD}\end{array}$} & \multirow{2}{*}{$\begin{array}{l}\text { DC }(n=6) \\
\text { Mean } \pm S D\end{array}$} & \multirow{2}{*}{$\begin{array}{l}\text { WP }(n=6) \\
\text { Mean } \pm S D\end{array}$} & \multirow{2}{*}{$\begin{array}{l}\text { GK }(n=6) \\
\text { Mean } \pm S D\end{array}$} & \multirow{2}{*}{$\begin{array}{l}\text { WPGK }(n=6) \\
\text { Mean } \pm \text { SD }\end{array}$} & \multicolumn{2}{|l|}{ ANOVA } \\
\hline & & & & & & $F$ value & Sig. \\
\hline WBC $\left(10^{3} \mu l\right)$ & $10.8 \pm 1.2$ & $18.4 \pm 5.3$ & $13.1 \pm 3.2$ & $19.0 \pm 4.4$ & $15.2 \pm 3.9$ & 3.6 & $0.022^{*}$ \\
\hline $\operatorname{RBC}\left(10^{6} \mu \mathrm{l}\right)$ & $8.0 \pm 0.5$ & $8.0 \pm 0.5$ & $7.5 \pm 0.6$ & $7.8 \pm 0.6$ & $8.5 \pm 0.5$ & 3.0 & $0.044^{*}$ \\
\hline $\mathrm{Hgb}(\mathrm{g} / \mathrm{dl})$ & $15.1 \pm 1.1$ & $16.0 \pm 0.7$ & $15.1 \pm 1.1$ & $14.9 \pm 1.2$ & $15.9 \pm 0.5$ & 1.8 & 0.175 \\
\hline Hct (\%) & $44.3 \pm 3.8$ & $46.4 \pm 1.6$ & $44.1 \pm 2.7$ & $44.0 \pm 3.5$ & $46.6 \pm 1.0$ & 1.4 & 0.257 \\
\hline MCV (fl) & $55.5 \pm 2.1$ & $58.3 \pm 2.5$ & $58.8 \pm 0.8$ & $56.4 \pm 1.1$ & $54.7 \pm 2.6$ & 4.2 & $0.012^{*}$ \\
\hline $\mathrm{MCH}(\mathrm{pg})$ & $18.9 \pm 0.6$ & $20.1 \pm 1.0$ & $20.1 \pm 0.5$ & $19.1 \pm 0.5$ & $18.7 \pm 0.9$ & 4.3 & $0.010^{* *}$ \\
\hline $\mathrm{MCHC}(\mathrm{g} / \mathrm{dl})$ & $34.2 \pm 0.8$ & $34.5 \pm 0.6$ & $34.2 \pm 0.7$ & $33.9 \pm 0.5$ & $34.2 \pm 0.5$ & 0.7 & 0.629 \\
\hline RDW (\%) & $11.9 \pm 0.6$ & $12.1 \pm 0.9$ & $12.7 \pm 1.1$ & $11.0 \pm 0.5$ & $11.8 \pm 0.8$ & 3.0 & $0.040^{*}$ \\
\hline $\operatorname{PLT}\left(10^{3} \mathrm{ml}\right)$ & $613.3 \pm 88.5$ & $794.7 \pm 83.6$ & $837.2 \pm 238.5$ & $715.4 \pm 29.8$ & $775.0 \pm 60.3$ & 2.3 & 0.094 \\
\hline MPV (fL) & $5.7 \pm 0.4$ & $6.0 \pm 0.1$ & $5.4 \pm 0.2$ & $6.1 \pm 0.4$ & $5.7 \pm 0.3$ & 4.4 & $0.010^{* *}$ \\
\hline
\end{tabular}

NC normal control; DC diabetic control; WP whey protein; OL olive leaves; WPOL whey protein and olive leaves; $n$ number of rats, SD standard deviation, and ANOVA analysis of variance; WBC white blood cells; RBC red blood cells; Hgb hemoglobin; Hct hematocrit; $M C V$ mean corpuscular volume; $M C H$ mean corpuscular hemoglobin; $M C H C$ mean corpuscular hemoglobin concentration, RDW red cell distribution width; PLT platelet count; $M P V$ mean platelet volume Values subscribed in the same row with different letters showed significant differences $(P<0.05)$ between these values as calculated by ANOVA and LSD ${ }^{*} P<0.05,{ }^{* *} P<0.01$ and ${ }^{* * *} P<0.001$ 
Table 3 Mean \pm SD of biochemical markers of diabetic rats fed on whey protein, olive leaves extracts and their mixture

\begin{tabular}{|c|c|c|c|c|c|c|}
\hline & $\mathrm{NC}(n=6)$ & $\mathrm{DC}(n=6)$ & WP $(n=6)$ & $\mathrm{OL}(n=6)$ & WPOL $(n=6)$ & ANOVA \\
\hline & Mean \pm SD & Mean \pm SD & Mean \pm SD & Mean \pm SD & Mean \pm SD & $F$ value \\
\hline Glucose (mg/dl) & $66.0 \pm 5.8$ & $135.6 \pm 12.3$ & $61.0 \pm 10.8$ & $64.8 \pm 14.6$ & $91.7 \pm 20.0$ & $30.9^{* * *}$ \\
\hline Cholesterol (mg/dl) & $48.0 \pm 6.4$ & $37.8 \pm 6.6$ & $42.2 \pm 7.3$ & $55.0 \pm 10.4$ & $48.7 \pm 6.56$ & $4.4^{* *}$ \\
\hline Triglycerides (mg/dl) & $29.8 \pm 6.4$ & $16.6 \pm 3.1$ & $27.4 \pm 4.9$ & $32.5 \pm 5.68$ & $31.2 \pm 6.62$ & $5.6^{* *}$ \\
\hline Total protein $(\mathrm{g} / \mathrm{l})$ & $5.9 \pm 0.4$ & $6.5 .1 \pm 1.9$ & $6.45 \pm 0.2$ & $6.95 \pm 1.74$ & $6.30 \pm 0.68$ & 2.1 \\
\hline Albumin (g/l) & $2.4 \pm 0.0$ & $2.4 \pm 0.2$ & $2.6 \pm 0.2$ & $2.81 \pm 0.27$ & $2.57 \pm 0.18$ & $3.4^{*}$ \\
\hline AST (U/I) & $142.8 \pm 16.6$ & $204.7 \pm 13.2$ & $37.5 \pm 1.3$ & $130.2 \pm 16.0$ & $77.8 \pm 16.8$ & $126.0^{* * *}$ \\
\hline $\operatorname{ALT}(\mathrm{U} / \mathrm{l})$ & $35.4 \pm 8.3$ & $48.0 \pm 9.2$ & $45.8 \pm 5.0$ & $34.8 \pm 6.2$ & $27.5 \pm 5.9$ & $8.3^{* * *}$ \\
\hline $\operatorname{ALP}(\mathrm{U} / \mathrm{l})$ & $604.6 \pm 97.4$ & $660.8 \pm 183.4$ & $921.0 \pm 53.5$ & $471.2 \pm 115.6$ & $633.8 \pm 89.7$ & $11.8^{* * *}$ \\
\hline Urea (mg/dl) & $14.9 \pm 1.8$ & $31.0 \pm 5.2$ & $86.0 \pm 6.9$ & $110.8 \pm 30.2$ & $121.1 \pm 24.3$ & $38.7^{* * *}$ \\
\hline Creatinine (mg/dl) & $0.03 \pm 0.01$ & $0.01 \pm 0.003$ & $0.03 \pm 0.01$ & $0.23 \pm 0.07$ & $0.23 \pm 0.10$ & $23.6^{* * *}$ \\
\hline
\end{tabular}

NC normal control; DC diabetic control; WP whey protein; OL olive leaves; WPOL whey protein and olive leaves

$n$ number of rats, $S D$ standard deviation, and ANOVA analysis of variance

Values subscribed in the same row with different letters showed significant differences $(P<0.05)$ between these values as calculated by ANOVA and LSD

${ }^{* *} P<0.05,{ }^{* *} P<0.01$, and ${ }^{* * *} P<0.001$

and olive leaves extract may cause more glucose to be utilized by the body and it may also stimulate the release of insulin. Moreover, whey protein, G. kola, and olive leaves may have inhibitory properties against the activities of $\alpha$-amylases from human saliva and pancreas. The chemical characterization of phyto-constituents and antidiabetic properties of G. kola and olive leaves can be investigated through the inhibitory effect depending on the key enzyme linked to type- 2 diabetes ( $\alpha$-amylase and $\alpha$-glucosidase) which they are used in the management/ prevention of type 2 diabetes (Oboh et al. 2012; Mousa et al. 2014; Ajibola and Satake 1992; Blaide 1991; Orie and Ekon 1993). The reduction of blood glucose level by G. kola, whey protein, and olive leaves extract is in agreement with similar findings reported by Blaide (1991), and Orie and Ekon, (1993).
The researchers found that blood glucose level decreased in several animal studies that used individual whey protein, G. kola, and olive leaves extract, and all of that studies advocated that this hypoglycemic effect may be attributed to the reduction in digestion and absorption of starch and subsequently reduced blood glucose (Mousa et al. 2014; Ajibola and Satake 1992). In the present study, there was an evident improvement in the level of some blood markers, enzyme activities, and brain histology. Eidi et al. (2009) reported that the oral administration of the olive leaves extract $(0.1,0.25$, and $0.5 \mathrm{~g} / \mathrm{kg}$ body $\mathrm{wt}$ ) for 14 days decreased significantly the serum glucose, total cholesterol, triglycerides, urea, uric acid, creatinine, aspartate amino transferase (AST), and alanine amino transferase (ALT) while it increased the serum insulin in diabetic rats only. Consumption of olive

Table 4 Mean \pm SD of biochemical markers of diabetic rats fed on whey protein, $G$. kola, and their mixture

\begin{tabular}{|c|c|c|c|c|c|c|}
\hline & $\mathrm{NC}(n=6)$ & $\mathrm{DC}(n=6)$ & WP $(n=6)$ & GK $(n=6)$ & WPGK $(n=6)$ & ANOVA \\
\hline & Mean \pm SD & Mean \pm SD & Mean \pm SD & Mean \pm SD & Mean \pm SD & $F$ value \\
\hline Glucose (mg/dl) & $66.0 \pm 5.8$ & $135.6 \pm 12.3$ & $61.0 \pm 10.8$ & $68.5 \pm 6.6$ & $82.2 \pm 8.4$ & $65.2^{* * *}$ \\
\hline Cholesterol (mg/dl) & $48.0 \pm 6.4$ & $37.8 \pm 6.6$ & $42.2 \pm 7.3$ & $39.7 \pm 7.9$ & $43.5 \pm 4.8$ & 1.8 \\
\hline Triglycerides (mg/dl) & $29.8 \pm 6.4$ & $16.6 \pm 3.1$ & $27.4 \pm 4.9$ & $83.0 \pm 12.6$ & $45.8 \pm 5.8$ & $74.2^{* * *}$ \\
\hline Total protein $(\mathrm{g} / \mathrm{l})$ & $5.9 \pm 0.4$ & $6.5 .1 \pm 1.9$ & $6.45 \pm 0.2$ & $6.30 \pm 0.8$ & $6.9 \pm 0.4$ & $3.1^{*}$ \\
\hline Albumin (g/l) & $2.4 \pm 0.0$ & $2.4 \pm 0.2$ & $2.6 \pm 0.2$ & $3.1 \pm 0.7$ & $2.8 \pm 0.1$ & $4.2^{*}$ \\
\hline AST $(U / \mathrm{I})$ & $142.8 \pm 16.6$ & $204.7 \pm 13.2$ & $37.5 \pm 1.3$ & $121.7 \pm 28.5$ & $155.5 \pm 35.8$ & $46.5^{* * *}$ \\
\hline $\operatorname{ALT}(\mathrm{U} / \mathrm{l})$ & $35.4 \pm 8.3$ & $56.0 \pm 1.2$ & $45.8 \pm 5.0$ & $49.4 \pm 1.5$ & $46.7 \pm 3.6$ & $5.7^{*}$ \\
\hline $\operatorname{ALP}(\mathrm{U} / \mathrm{l})$ & $604.6 \pm 97.4$ & $660.8 \pm 183.4$ & $921.0 \pm 53.5$ & $641.0 \pm 166.4$ & $676.0 \pm 68.6$ & $5.8^{* *}$ \\
\hline Urea $(\mathrm{mg} / \mathrm{dl})$ & $14.9 \pm 1.8$ & $31.0 \pm 5.2$ & $86.0 \pm 6.9$ & $37.3 \pm 5.7$ & $80.5 \pm 3.7$ & $219.3^{* *}$ \\
\hline Creatinine (mg/dl) & $0.03 \pm 0.01$ & $0.01 \pm 0.003$ & $0.03 \pm 0.01$ & $0.071 \pm 0.14$ & $0.05 \pm 0.02$ & $130.5^{* *}$ \\
\hline
\end{tabular}

NC normal control; DC diabetic control; WP whey protein; GK G. kola; and WPGK whey protein and G. kola

$n$ number of rats, SD standard deviation, and ANOVA analysis of variance

Values subscribed in the same row with different letters showed significant differences $(P<0.05)$ between these values as calculated by ANOVA and LSD

${ }^{*} P<0.05,{ }^{* *} P<0.01$, and ${ }^{* * *} P<0.001$ 
Table 5 Effect of administration of whey protein mixed with Garcinia kola and olive leaves on histological picture of brain in diabetic rats

\begin{tabular}{|c|c|c|c|c|c|c|}
\hline & Perivascular Edema & Congested blood vessels & Neuronal necrosis & Neuronal chromatolysis & Axonal demylenation & Hemorrhage \\
\hline NC & + & + & + & + & + & - \\
\hline DC & ++++ & +++ & +++ & +++ & +++ & - \\
\hline WP & - & - & - & - & - & - \\
\hline $\mathrm{OL}$ & + & + & - & - & - & - \\
\hline WPOL & - & - & - & - & - & - \\
\hline GK & - & - & - & - & - & - \\
\hline WPGK & - & - & - & - & - & - \\
\hline
\end{tabular}

NC normal control; DC diabetic control; WP whey protein; OL olive leaves; WPOL whey protein and olive leaves; GK G. kola; and WPGK whey protein and G. kola $(++++)$ severe; $(+++)$ moderate; $(+)$ present and $(-)$ normal

leaves extract resulted in non-significant changes in RBCs, hemoglobin, hematocrit, and $\mathrm{MCH}$ values. It was reported that many hematologic abnormalities have been defined in diabetic subjects; however, there is lack of classic hematologic pathologic findings in this condition (Jones and Peterson, 1981). Results obtained in the present investigation revealed that the nervous system is affected by diabetic toxicity. Cellular changes were noticed in untreated diabetic rats including generalized and localized edema in the white matter of the cerebrum and cerebellum. Moreover, diabetes caused neuronal degeneration; neuronal necrosis, neuronal chromatolysis and axonal demylenation. These changes could be partially due to oxidative stress secondary to diabetic neurotoxicity. Treatment of diabetic rats with whey protein, G. kola, and olive leaves extract improved the histological picture, and data can be investigated that olive leaves could have anti-oxidative properties or may have anti-excitotoxic effect. The potential beneficial promoting health effect after administration of whey protein, G. kola, and olive leaves extract appear to be linked to its antioxidant activity which was found to be helpful in the prevention of diabetic complications associated with oxidative stress. McIntosh et al. (1995) reported that when different groups of rats were given a powerful substance-induced oxidative stress and carcinogenic with administration of whey protein concentrate showed fewer tumors and reduced tumor masses. Also, they added that rats fed a whey protein-based diet had a lower risk of developing the oxidative stress and carcinogen. The obtained data was in agreement with some earlier reports of epidemiological findings and studies which aimed to study the influence of dairy products intake on the developed risks and oxidative stress (Lee et al. 2013; Zhao et al. 2013; Reno et al. 2013; Akintonwa and Essein 1990; Blaide 1991; Orie and Ekon 1993). They found that the major milk proteins, casiens, whey proteins, and membrane structures might all exert preventive effect of oxidative stress factors. Whey protein was found to be protective against the oxidative stress and lipid peroxidation, which was being associated with an increase in the intracellular levels of glutathione $(\mathrm{GSH})$, where whey is a prime source of precursors. When liver antioxidant enzyme levels rise, the liver is able to more effectively detoxify the body, in addition, un-denatured whey protein optimizes serum and liver enzymes (McIntosh et al. 1995).

\section{Conclusions}

Data can be concluded that the administration of whey protein, G. kola, and olive leaves extract improved some of hematological and biochemical parameters as well as the brain histological picture of diabetic rats. Also, the administration of whey protein, G. kola, and olive leaves extract demonstrated to reduce diabetes risk and improve glycemic control.

\section{Acknowledgements \\ The authors would like to thank the technical staff members in Food Science and Human Nutrition Department, College of Agriculture and Veterinary Medicine, Qassim University, Buraidah, Saudi Arabia for their cooperation.}

Funding

This research did not receive any specific grant from funding agencies in the public, commercial, or not-for-profit sectors.

\section{Availability of data and materials}

All necessary data supporting our findings can be found in the repository.

\section{Authors' contributions}

AMA-S conceived and designed the experiments; formulated the whey protein, Garcinia kola seeds, and olive leaves diet; performed the animal procedures and biological evaluation of whey protein, Garcinia kola seeds, and olive leaves diet; analyzed and performed the blood biochemical analysis and data analysis; and wrote the paper. MSI conceived and designed the experiments; performed the animal procedures and biological evaluation of whey protein, Garcinia kola seeds, and olive leaves diet; analyzed and performed the blood biochemical analysis and data analysis; and wrote the paper. MMF performed the histopathological investigations and data analysis and wrote the paper. HMM conceived and designed the experiments; performed the animal procedures and biological evaluation of whey protein, Garcinia kola seeds, and olive leaves diet; analyzed and performed the blood biochemical analysis and data analysis; and wrote the paper. All authors read and approved the final manuscript.

\section{Ethics approval}

Animal procedures were performed in accordance with the ethics committee of Qassim University, Research Ethics Committee (Saudi Arabia) 
and according to the Guide for the Care and Use of Laboratory Animals of the National Institute of Health.

\section{Consent for publication}

Not applicable

\section{Competing interests}

The authors declare that they have no competing interests.

\section{Publisher's Note}

Springer Nature remains neutral with regard to jurisdictional claims in published maps and institutional affiliations.

\section{Author details}

'Dairy Science Department, National Research Centre, Dokki, Cairo, Egypt. ${ }^{2}$ Nutrition and Food Science Department, Faculty of Home Economic, Menoufia University, Shibîn El-Kôm, Al Minufiyah, Egypt. ${ }^{3}$ Development and Innovation Center, Tabil Food Industries, Khartoum, Sudan. ${ }^{4}$ Food Science and Human, Nutrition Department, College of Agriculture and Veterinary Medicine, Qassim University, Buraidah, Saudi Arabia.

Received: 19 July 2018 Accepted: 25 September 2018

Published online: 22 October 2018

\section{References}

Abaza L, Talorete TPN, yamada P, Kurita y, zarrouk M, Isoda H (2007) Induction of Growth Inhibition and Differentiation of Human Leukemia HL-60 Cells by a Tunisian Gerboui Olive Leaf Extract. Biosci. Biotechnol. and Biochem. 71 1306-1312.

Abdel-Salam AM, Ammar AS, Galal WK (2009) Evaluation and properties of formulated low calories functional yoghurt cake. J Food Agric Environ 7:218-221

Ajibola AO, Satake M (1992) Contributions to the phytochemistry of medicinal plants growing in Nigeria as reported in the 1979-1990 literature-a preview. Afr J Pharm Sci 22:172-201

Akintonwa A, Essein AR (1990) Protective effects of Garcinia kola seed against paracetamol-induced hepatoxicity in rats. J Ethnopharmacol 29:207-211

Andreadou I, Iliodromitis EK, Mikros E, Constantinou M, Agalias A, Magiatis P, Skaltsounis AL, Kamber E, Tsantili-Kakoulidou A (2006) The olive constituent uropein exhibits anti-ischemic, antioxidative and hypolipidemic effects in anesthetized rabbits. J Nutr 136:2213-2219

Atawodi S, Mende P, Pfundstein B, Preussmann R, Spiegelhalier B (1995) Nitrosatable amines and nitrosomide formation in natural stimulants, Cola acuminata, Cola nitida and Garcinia kola. Food Chem Toxicol 33:625-630

Bagheri S, Ahmadvand H (2011) Effects of olive leaves extract on LDL oxidation induced-CuSO4 in vitro. Clin Biochem 44(13):S345

Baruchel S, Viaux G (1996) In vitro selective modulation of cellular glutathione by a humanized native milk protein isolate in mammal cells and rat mammary carcinoma model. Anticancer Res 15:1095-1100

Bitler CM, Viale TM, Damaj R, Crea R (2005) Hydrolyzed olive vegetation water in mice has anti-inflammatory activity. J Nutr 135:1475-1479

Blaide VD (1991) Pharmacology effects of chronic ingestion of Garcinia kola seeds in the rats. Phtother Res 4:39-41

Bloomgarden ZT (2002) The epidemiology of complications. Diabetes Care 25: 924-932

Bonnes RW, Taussky HH (1945) On the calorimetric determination of creatinine by the Jaffe reaction. J Biol Chem 158:158591

Brodrick JM, Colloby PS, Legg EF (1987) Comparison of two new ward-based glucose meters. Prac Diabetes Int 4:170-172

Carluccio MA, Siculclla L, Ancora MA, Scoditti E, Storelli C, Visioli F, Distante A, DeCaterina R (2003) Olive oil and red wine antioxidant polyphenols inhibit endothelial activation. Arterioscler Thromb Vasc Biol 23:622-629

Drupt F (1974) Colorimetric method for determination of albumin. Pharm Biol 1: 777-779

Eidi A, Eidi M, Darzi R (2009) Antidiabetic effect of Oleaeuropaea L. in normal and diabetic rats. Phytother Res 23(3):347-350

European directive (2010) Euro science supports directive on the protection of animals used for scientific purposes. Euro Sci Newsl 1(2010):63/EU

Fossati P, Prencipe L (1982) Serum triglycerides determined Colorimetrically with an enzyme that produces hydrogen peroxide. Clin Chem 28:2077-2080
Gannon MC, Nuttall FQ, Neil BJ, Westphal SA (1988) The insulin and glucose responses to meals of glucose plus various proteins in type II diabetic subjects. Metabolism 37:1081-1088

García AM, Moumen A, Ruiz DY, Alcaide EM (2003) Chemical composition and nutrients availability for goats and sheep of two-stage olive cake and olive leaves. Anim Feed Sci Technol 107:61-74

Humason GL (1979) Animal Tissue Techniques, 4th edn. W. H. Freeman and Company, San Francisco

Jones RL, Peterson CM (1981) Hematologic alterations in diabetes mellitus. Am J Med 70(2):339-352

Kind PRN, King EJ (1954) Estimation of plasma phosphatase by determination of hydrolysed phenol with aminoantipyrine. J Clin Pathol 7:322-326

King EJ, Woolton IDP (1956) Microanalysis in Medical Biochemistry. A. Churchill Ltd, London, p 91

Konok GP, Bounous G, Baruchel S, Lee TD (1995) The use of a whey protein concentrates in the treatment of patients with metastatic carcinoma: phase I-Il clinical study. Anticancer Res 15(6B):2643-2650

Lee JH, Yoon S, Renshaw PF, Kim TS, Jung JJ, Choi Y, Kim BN, Jacobson AM, Lyoo IK (2013) Morphometric changes in lateral ventricles of patients with recentonset type 2 diabetes mellitus. PLoS One 4(8):60515

Markin D, Duek L, Berdicevsky I (2003) In vitro antimicrobial activity of olive leaves. Mycoses 46:132-136

McIntosh GH, Regester GO, Le LR, Royle PJ, Smithers GW (1995) Dairy proteins protect against dimethylhydrazine-induced intestinal cancers in rats. J Nutr 125:809-816

Mousa HM, Farahna M, Ismail MS, Al-Hassan AA, Ammar AS, Abdel-Salam AM (2014) Anti-diabetic effect of olive leaves extract in alloxan-diabetic rats. J Agric Vet Sci 7(2):181-196

Nagpal R, Behare P, Rana R, Kumar A, Kumar M, Arora S, Morotta F, Jain S, Yadav $H$ (2011) Bioactive peptides derived from milk proteins and their health beneficial potentials: an update. Food Funct 2:18-27

Oboh G, Akinyemi AJ, Ademiluyi AO (2012) Inhibition of a-amylase and aglucosidase activities by ethanolic extract of Telfairia occidentalis (fluted pumpkin) leaf. Asian Pac J Trop Biomed 2(9):733-738

Orie NN, Ekon EU (1993) The bronchodilator effects of Garcinia kola. Afr J Pharm Sci 22:172-201

Reitman S, Frankel S (1957) A colorimetric method for the determination of serum glutamic oxalacetic and glutamic pyruvic transaminases. Amer J Clin Pathol 28:56-63

Reno CM, Tanoli T, Bree A, Daphna-Iken D, Cui C, Maloney SE, Wozniak DF, Fisher SJ (2013) Antecedent glycemic control reduces severe hypoglycemiainduced neuronal damage in diabetic rats. Am J Physiol Endocrinol Metab 15(12):1331-1337

SAS (1996) SAS/ Stat Users Guide: Statistics, System for Windows, version 4.10 (release 8.01 TS level 01M0). SAS Inst., Inc, Cary

Sato H, Genet C, Strehle A, Thomas C, Kobstein A, Wahner A, Mioskowski C, Auwerx J, Saladin R (2007) Anti-hyperglycemic activity of a TGR5 agonist isolated from a europaea. Biochem Biophys Res Commun 362:793-798

Sharma S, Singh R, Rana S (2011) Bioactive peptides. Rev Int J Bioautom 215:223-250

Steel R, Torrie J, Dickey D (1997) Principles and procedures of statistics: a biometrical approach, 3rd edn. McGraw-Hill, New York

Tietz NW (1970) Fundamentals of clinical chemistry. W. B. Saunders Co., Philadelphia

Tita RK, Odeigah PG, Agomo PU, Bassey E (2001) Some properties of medicinal plants used by the Igbos in Nigeria. In: Wolfgang K (ed) Trials, tracts and traces. GE Scientific Publishers, Mannheim, pp 209-210

Tuck KL, llayball PJ (2002) Major phenolic compounds in olive oil: metabolism and health effects. J Nutr Biochem 13:636-644

Wainstein J, Ganz T, Boaz M, Bar Dayan Y, Dolev E, Kerem Z, Madar Z (2012) Olive leaf extract as a hypoglycemic agent in both human diabetic subjects and in rats. J Med Food 15:605-610

World Health Organization (WHO) (2009) Cardiovascular Diseases [home page on the internet]. [cited 2009 Oct 11]. Available from: http://www.who.int/ cardiovascular_diseases/en〉.

Zhao B, Pan BS, Shen SW, Sun X, Hou ZZ, Yan R, Sun FY (2013) Diabetesinducedcentralneuritic dystrophy and cognitive deficits are associated with theformation of oligomeric reticulon-3 via oxidative stress. J Biol Chem 31:15590-15599 